\title{
Making Fundamental Changes in Education: Is "Whole Language" Feasible?
}

\section{Garon Wheeler}

The possibility that a novel method, theory, or approach may have a history and may in fact not even be new is often overlooked by educators. A recent example of this is the interest in what is termed Whole Language, which has been presented as an innovation addressing many perceived deficiencies of traditional education. Nevertheless, the precepts of Whole Language can be traced to a change in attitude toward students in the 1600 s and 1700 s that laid the foundations of modern education. History shows that Whole Language faces many obstacles in its quest for widespread acceptance. First, it takes us back to the ancient notion of teaching as an art rather than a science. Furthermore, Whole Language is unable to demonstrate its superiority with statistics, which is a requirement for introducing radical changes. The tendency to avoid substantial change is thus expected to prevail.

It has already started. It is only 1995, but we are reading and hearing about education and teaching in the 21st century. It is inevitable and worthwhile that we assess our profession over the next few years. As a historian of linguistics and language teaching, I find it profitable at this time to look back as well as ahead. In this article I focus on an up-to-date topic, Whole Language, but mostly from a historical point of view. Although I spend the first part praising Whole Language and wishing it all the best, I then discuss why I am not optimistic about its long-term survival. Along the way I say a few kind words about so-called "traditional teachers."

Let us begin with a brief summary of what Whole Language is. Originally thought of as a way to teach reading, it is now seen by its adherents as the key to all aspects of language learning. It is still often associated with younger pupils as they learn their native language, but in recent years its possibilities in foreign language instruction for all levels and ages have been recognized (Freeman \& Freeman, 1992; Heald-Taylor, 1989; Hedgecock \& Pucci, 1993; Lim \& Watson, 1993). Here, necessarily simplified, are what most people will agree are the starting points for the approach (for more detail, see Altwerger \& Flores, 1991; Gursky, 1991):

1. Reading, writing, speaking, and listening should be based on similar principles and processes.

2. Language should not be taught in a fragmented manner.

3. Working on one aspect of language (e.g., reading) automatically helps other aspects, such as spelling, grammar, and punctuation. 
4. Language is a meaning-centered activity and, above all, is meant to make sense.

5. Language is learned through use. One learns to read by reading, to write by writing, and so forth.

A fundamental belief of Whole Language is that learning should be based on the interests of the student-within reason, of course, because there are still requirements to fulfill and objectives to meet. Moreover, giving the students a choice is important in Whole Language. Whenever possible, students are responsible for what they read and are the judges of what is the appropriate level. One may compare these beliefs with those advocated in so-called traditional classrooms, where the syllabus imposes the level. This concern for independence of thought underscores Whole Language's aversion to the emphasis on memorization and recitation that has always been found in much of education. Finally, Whole Language places great importance on the psychological state of the student. Feeling comfortable in the classroom and being free from anxiety are regarded as the most basic requirements for effective acquisition. These are the starting points for self-confidence and the motivation to learn.

In practice, adopting a Whole Language approach means abandoning many standard tactics and tools: Whole Language elementary teachers no longer rely on basal readers, for example; in ESL teachers eliminate familiar textbooks focusing on the separate skills. It signals the end of reading passages chosen especially for their grammatical content or simple vocabulary, and of comprehension and grammar exercises. The focus is instead on reading and producing "authentic" texts that have relevance to the students. At any level, students tackle the whole of language at once instead of its components. Otherwise, say Altwerger and Flores (1991), "It would be as if separate pedaling, handlebar holding, steering, and brake-applying did not need to be integrated, as if they could simply be added together to produce bike riding" (p. 101). It is a hands-on philosophy where the students learn every aspect of language by using it in meaningful situations to communicate. Above all, it is an approach based on literacy. Reading is the catalyst for acquiring all the other language skills.

Informally survey teachers, and the definition of Whole Language will predictably be more general. "It means not separating the individual skills," or something to that effect. Quite a few teachers will tell you that they were using many of the ideas of Whole Language long before they had ever heard of it. Rather than setting a trend or copying one, they were simply following what seemed to be the natural or obvious way to go about things.

So here it is: Whole Language. It has become established in many places and is causing a sensation in others around the world, and it is not hard to see why. It has the excitement and charisma that go with innovation. It is a student-centered approach that gives the teacher freedom and responsibility 
beyond the traditional boundaries, and for those who have sought this, Whole Language is the answer to a prayer. Moreover, to the joy of those who believe in it, it works.

Now for the bad news: I fear the future is not bright for Whole Language. I am not going to discuss the considerable practical obstacles to implementing Whole Language, such as the requirement of additional classroom resources or teacher training or political considerations. Those are matters more of fact than opinion. Instead, I would like to mention two categories of difficulties. The first is simply my own reaction and perhaps of less consequence; the other is based on history.

The first problem involves the justification behind the entire movement. I am struck by the use of straw-man arguments in the interest of advancing Whole Language. Again and again, Whole Language is held up as the solution to the ills of the traditional classroom. Unfortunately and unfairly, the traditional classroom fares extremely poorly in these arguments. Traditional teachers are presented as "technicians" following a script, for example (Gursky, 1991, p. 24), or "managers of commercially produced materials" (p. 28), or even "police officers" (Rigg, 1991, p. 359). In short, they are seen as not much more than soulless automatons. Even worse are the arguments by implication. Goodman (1992), the godfather of Whole Language, says, for example, "Whole language classrooms are safe havens for all who live there. Pupils have a right to feel comfortable and safe from physical, mental, or social abuse" (p. 361). I was not aware that physical, mental, and social abuse were part of the traditional curriculum. He says "Pupils have the right to choose the groups they will join, but they also ... [develop] the understanding that no one may be excluded or hurt by the group," and "In whole language classrooms ... each treats the others with respect, and legitimate requests for help are not denied." Are insensitivity and disrespect condoned by any competent teacher of any teaching philosophy? The comment that I take most personally regards his view of eclecticism. I have always preached the idea that one should take useful techniques from any source. Goodman, however, asserts that "eclecticism is probably the best policy for teachers ... who don't have a well-articulated belief system and knowledge base." Then, as though they are on a higher spiritual plane, he informs us "Whole Language teachers ... are beyond eclecticism." These are rather odd comments, as the Whole Language teachers I know find that a 100\% pure classroom is impossible for many reasons. Nevertheless, these emotional arguments, which are typical of new movements, are the least effective. Traditional teachers are made to look like buffoons. Anyone who knows how to think, the arguments imply, will be a Whole Language teacher. These arguments, however, often seem to have little to do with Whole Language versus tradition. Rather, it is often a simple, legitimate question of good teaching versus bad. A Whole Language classroom may differ from a traditional one in some 
fundamental ways, but it certainly is a mistake to associate creativity and concern for one's students exclusively with Whole Language.

Nevertheless, the bigger obstacle that Whole Language will have to overcome is history, and all I can say about that is "Good luck." It will not be easy to fight over 2,000 years of Western education. Much of Whole Language is not as new as it looks, while the parts, if any, that may be considered innovative will find difficulty in surviving in recognizable form.

Interest in the psychological welfare of the student has not always been a tenet of education, but to assign a place of honor in this regard to Whole Language is misguided. It really has been only in the last 300 to 400 years that educators even attempted to attract the interest of their charges. Just a look at a typical schoolbook from the 1600 s is sufficient to leave one astonished that anybody, child or adult, could ever plod through such a tome with open eyes. Gradually one finds more humane methods beginning to appear in the 17 th century. Comenius, a famous Czech educator, had the unusual idea that students should be interested in what they study; the result was the first illustrated textbook. Lancelot wrote a popular series of grammar books in France that put the dull rules into little verses for easy memorization. He also made sure that his books had more explanations than ever before, rather than cold, bare models (Tsiapera \& Wheeler, 1993; for a readable introduction to the evolution of education, see Rusk, 1979). These are only examples of ideas that attracted attention and had some effect, but that were not influential enough to revolutionize education. Their effects were more like those of a ripple on a pond: eventually widespread but in diluted form.

Jean-Jacques Rousseau, philosopher of the next century and one of the greatest thinkers of all time, believed that education should be based on experience and contact with nature. Students should initiate learning and their interests should serve as the basis for their education. The stages of education, he declared, should match those of the child's development. These are indeed impressive words. Never mind that he also believed children were not ready for schooling until the age of 12 .

Johann Heinrich Pestalozzi tried to put Rousseau's idea to work in his native Switzerland about 200 years ago. He was quite successful in his efforts to make experiences and observation the basis of education rather than talk and memorization. His ideas reached into Germany and then across the Atlantic to the United States.

In the 19th century, Johann Friedrich Herbart continued the work of Pestalozzi. The teacher's role was to build a base of ideas from the interests of the student. Ideas are dynamic, he said; they seek other ideas in a sort of chain reaction. Friedrich Froebel, the founder of kindergarten, emphasized self-development through creativity and spontaneity. Group unity was considered essential as well. 
At the turn of the century, we find John Dewey, who is widely seen as the most influential educator in American history. He is also the spiritual guru of the Whole Language movement, the man whose words are so often evoked today to clothe Whole Language with historical legitimacy. Here are the tenets of his educational philosophy:

- The interests of the child should be the basis of educational procedures: start with these and develop them.

- Education is achieved through the interaction of activities with ideas, doing as well as thinking.

- School should be a "miniature community"; it should be a reflection of real life.

- The teacher should direct and work with the students, not dictate forced lessons.

These are familiar themes, especially to a Whole Language teacher. I hope it is clear as well that Dewey's ideas were hardly original and were instead a reformulation of recurring ideas. That is how I see the Whole Language movement in simplest terms: the reformulation of ideas that have been around for a long, long time. A cynical way to view them is to say that if they are so "correct" they would have become standard by the 19th century. A more generous opinion is that they have stayed with us because they are correct, no matter how difficult to implement. In truth, they have indeed had their effect; otherwise we would still be following medieval and Renaissance procedures. Dewey's ideas were eventually so distorted that by the last 20 years of his life he no longer wanted the responsibility of their ownership. Nevertheless, it is he who is to this day often blamed for the supposed decay of American education and its abandonment of the basics. "The basics" means textbooks, recitation, and above all memorization. Throughout history, the role of memorization and recitation has been extolled. One educational historian of nearly 100 years ago declared for all time:
Repetition is always good.... Repetition has been called the "mater studiorum," and in truth few points are of more vital importance ... Without constant, steady, persistent drilling on the same matter in the beginning of a student's career, no solid foundation for the future literary edifice can be hoped for. (Schwickerath 1904, pp. 463, 466)

This attitude has been the keystone of Western education since its inception over 2000 years ago. It is only a dream that Whole Language will come along and sweep it away.

Whole Language is up against a formidable opponent in science as well, and this may be the toughest of all. Psychology and linguistics have both long suffered from an inferiority complex in relation to their hard science relatives. I put them together here because their history has been quite similar for a considerable time. Until the last century, "science" permitted 
speculation, idle or otherwise. It was often highly theoretical and haphazard. With the industrial revolution and the marvels of technology, science gained the respectability that it has never lost, whereas the arts have often been equated with useless daydreaming. Ever since, for well over a century now, both psychology and linguistics have continuously sought respectability by applying scientific methods whenever possible for fear of being too closely associated with the arts. The Behaviorist school of psychology, based on concepts like stimulus and response and operant conditioning, was the most prominent result. Only what could be observed, measured, and recorded was permissible for study and consideration. In linguistics this led to predictable theories of language acquisition resulting from trial and error, and reward and punishment. And in education, particularly in language training, this philosophy brought about the heyday of drills and repetition. The culmination was the Audio-Lingual Method of teaching foreign languages in the 1960s. Endless drilling of a few patterns and dialogues was supposed to instill these in the brain, creating a framework on which the rest of the language could be erected.

The Audio-Lingual Method, however, was no improvement, and Behaviorism has seen many changes. Now psychology and linguistics are often based on a more cognitive approach, one that no longer despises guesswork about things we cannot measure. In linguistics, at least, this return to a more speculative approach is allowed because we know that we are dealing with theory and intangibles when we try to construct a model of language processing. In education, though, this is not so good, because even though we are still in the realm of theory, like it or not, we have people screaming for results.

All this leads to a fascinating paradox involving Whole Language and science versus art. Goodman (1992) is convinced that Whole Language "is based on sound, scientific knowledge of language, learning, teaching, curriculum, and how society influences language and learning" (p. 356). I am not nearly such an optimist, but let us suppose for the sake of argument that he is right and that Whole Language is based on sound scientific principles. In accordance with its philosophy, teachers will have much more responsibility. However, greater power to the teacher entails a much larger role for creativity and individuality in teaching, which takes us back to the ancient notion of teaching as an art. We thus find ourselves farther away than ever from that cachet of legitimacy that only scientific methods can bestow.

Widespread acceptance of Whole Language would be a revolution in the history of education, and this is undoubtedly what many teachers would like to bring about. In 1962, Kuhn wrote his influential essay entitled The Structure of Scientific Revolutions in which he examined the causes of radical shifts in thinking throughout history. Although he discussed the physical sciences in particular, he did not intend to exclude the social sciences. A revolution 
occurs when we are presented with an irresolvable problem that cannot be ignored and with which the standard practices cannot deal. A new way of doing things-a new paradigm, Kuhn calls it-takes over when it is more successful than the current paradigm and its competitors at solving a problem or problems that are generally recognized as urgent. By these criteria, Whole Language fails unquestionably. History shows us that as long as problems can be ignored or swept under the proverbial rug, fundamental change is highly unlikely. Just as big a hurdle is the test of demonstrating superiority of Whole Language over traditional methods. The only way to convince the world is through test results: the results of tests that are designed to measure the success of the traditional methods. Once again one is faced with the challenge of scientific respectability. The success of Whole Language is largely anecdotal: the literature is full of case studies and testimonials in favor of the approach, but the concrete results are lacking. Get those test results by any way necessary-changing the tests is the obvious one-and Whole Language will have traversed one of its greatest obstacles to permanent success. But notice the word permanent: a significant reason for the success that Whole Language has enjoyed so far, as Kuhn points out, is its promise of success as a new paradigm. Without concrete results, it will have to be by word of mouth, and I doubt that any revolution has ever been achieved through reputation alone.

So what does this herald for the future of Whole Language? It has already made impressive gains in much of the English-speaking world, but for Whole Language to stay with us for years to come, it will have to overcome the problems I have discussed. I think it is most probable that, like its predecessors, it will have a positive effect, but that traditional methods will eventually reign again, though perhaps in a manner more satisfactory to everyone. One thing should be very clear though. Tradition should not be made to equate with bad teaching. It should not be made the scapegoat of those who are dissatisfied with the teaching profession. To think that bad teachers will become good ones if they adopt Whole Language is as absurd as believing that a good teacher will become bad without Whole Language. The goals of traditional methods, as well as of Whole Language, are to create an enjoyable atmosphere where students want to learn. If it were only that simple, though, the means would have been decided by the ancient Greeks.

"We can't liberate pupils from the need to work hard to learn, but we can liberate them from useless drill and drudgery." Goodman said that in 1991 (p. 360). "I can't share the opinion of those who want their pupils to become wise only through suffering and work ... and who let them be crushed under the weight of a thousand useless difficulties ... I believe one should render studying even more agreeable than games" (Carré, 1971, p. 82). A Latin teacher from France named Guyot said that in the mid-17th century. The more things change, the more they stay the same. 


\section{The Author}

Garon Wheeler has taught English and linguistics in the United States, Italy, North Africa, and the Middle East. He is currently an assistant professor and the Director of the Intensive English Program at Huron University in Huron, South Dakota.

\section{References}

Altwerger, B., \& Flores, B. (1991). Whole Language: What's new? In C. Edelsky (Ed.), With literacy and justice for all: Rethinking the social in language and education. New York: Falmer Press.

Carré, I. (1971). Les pédagogues de Port-Royal. Geneva: Slatkine Reprints. (Facsimile of 1st ed. published 1887)

Freeman, Y., \& Freeman, D. (1992). Whole Language for second language learners. Portsmouth, $\mathrm{NH}$ : Heinemann.

Goodman, K. (1992). Why Whole Language is today's agenda in education. Language Arts, 69, 354-363.

Gursky, D. (1991). After the reign of Dick and Jane. Teacher Magazine, 108, August, 22-29.

Heald-Taylor, G. (1986). Whole Language strategies for ESL students. Toronto: OISE Press.

Hedgecock, J., \& Pucci, S. (1993). Whole Language applications to ESL in secondary and higher education. TESOL Journal, 3(2), 22-26.

Kuhn, T. (1962). The structure of scientific revolutions. Chicago, IL: Chicago University Press.

Lim, H.-J.L., \& Watson, D. (1993). Whole Language content classes for second-language learners. The Reading Teacher, 46, 384-393.

Rigg, P. (1991). Whole Language in TESOL. TESOL Quarterly, 25, 521-542.

Rusk, R. (1979 [1918]). Doctrines of the great educators (5th ed., revised by J. Scotland). New York: St. Martin's Press. (Original work published 1918)

Schwickerath, R. (1904). Jesuit education; Its history and principles viewed in the light of modern educational problems. St Louis, MO: Herder.

Tsiapera, M., \& Wheeler, G. (1993). The Port-Royal grammar: Sources and influences. Muenster: Nodus Publikationen. 